\title{
Graphic design in search of its identity
}

\author{
Kanupriya Taneja \\ Department of Design, Nirma University, Ahmedabad - 382481, India.
}

\begin{abstract}
To encompass the multitude of activities currently attached to graphic design, scholars, practitioners, and other stakeholders have proposed a range of names in recent times. Owing to the expansion of the role and multiple proposed and prevalent nomenclatures in education and industry, some confusion and identity crisis exists. This study investigates and traces the journey of graphic design, how its roles and functions have evolved with time, and the challenge of assigning a universally acceptable nomenclature encompassing all that graphic design stands for now. Data has been collected from both primary and secondary sources to get a sense of the situation. The secondary sources helped understand the breadth of the problem, views of scholars, practitioners, and the education world. Primary sources helped establish the inconsistencies of nomenclature in graphic design education, mirroring the situation of graphic design's expanded functions in the profession. Primary information has been collected from the design institutes' official websites in India, government documents, and reports to understand prevalent names of similar study programmes. The paper calls for shared and renewed efforts by design associations, scholars, practitioners, and educationists to access the profession's past, present, and future trajectory towards strengthening and reinforcing its identity.
\end{abstract}

Keywords: graphic design, expanded role \& function of graphic design, identity crisis, name change, the scope of graphic design, graphic design education in India

\section{Graphic Design in Search of Its Identity}

The book A Century of Graphic Design published by Aynsley [1, p. 6], informs that William Addison Dwiggins, a designer, devised the term "graphic design" in 1922 to create a distinction for different kinds of design for printing, namely book design, illustration, typography, lettering, and calligraphy. Before this, the graphics industry referred to itself as graphic arts as indicated in the name of the organization-American Institute of Graphic Arts formulated in the year 1914 to strengthen the profession of graphic design [2,3]. Aynsley [1] points out that a significant historical landmark was the mechanization of printing technology that gave impetus to advertising for reaching out to the mass markets. It led to the burgeoning rise of highly skilled workers who could illustrate for a variety of printing mediums to provide communication support to the demand of commerce. Further, graphic design gained acceptance compared to commercial arts, which were considered obsolete with its "skill-centric" connotations. The term commercial graphics had derogatory undertones of being inferior to fine arts which were not associated with commerce [1]. Thus, graphic design and graphic designers close links with printing technology goes back a long way. Further, conventional belief reduces the role of a graphic designer to a visualizer-one who organizes visual components, employing printing technology for the reproduction of his designs like logotypes, stationery, book and magazine layout, advertisements and campaigns, posters, packages (labels), exhibitions, displays, corporate identity systems, signage systems [4].

Since the beginning, graphic design's boundaries and identity have been in constant flux. The industry has been trying to keep pace 
with the vast and rapid changes in technology, marketplace conditions, business practices, social and cultural phenomena. The dynamic nature of the marketplace demands flexibility from graphic design practitioners, which in turn has a bearing on graphic design education. Literature shows that the role of graphic design has both changed and evolved over the years and continues to evolve. Daman [3], in her thesis titled From Margins to Mainstream, brings to notice that in the year 2000, AIGAThe Professional Association for Design collaborated with the U.S. Census of Business to extend the product list for the graphic design profession to 39 products or services. The list included advertising and promotion design, corporate identity design, design strategy, and management, editorial design, exhibit design, signage design, interaction design, motion graphics design, packaging design, illustration, information design, and design production, among others [AIGA, 2001, p.3 cited by Damon 3 p. 44]. As a consequence of expanded boundaries and the profession's portfolio, there are multiple titles and nomenclatures of graphic design in the present times, which has led to an identity crisis and confusion for its various stakeholders.

\section{What is Graphic Design?}

Design associations, educators, scholars, and practitioners have defined graphic design as relevant in their time and context. Some have emphasized the traditional role of graphic design limited to the aesthetic organization of elements with the help of design principles, and some stress on the outcome of products as a result of an act of designing. Form, content, and context are also considered essential ingredients of graphic design. The range of definitions reflects the profession's dynamic nature, its expanding role, and application beyond print media as understood traditionally.

Harland [5, p.24], while discussing the importance of dictionaries as a tool for reference for understanding the "special sub-divisions of knowledge" clarifies, the first edition of Dictionary of Graphic Design and Designers by Livingston Alan \& Isabella published in the early 1990s defines graphic design: "Generic term for the activity of combining typography, illustration, photography, and printing for the purpose of persuasion, information or instruction" [5, p.24]. The author further states that the second edition published retained the same definition in 2003; here, it was argued to be traditional and outdated. Aynsley [1, p.6] in the seminal book A Century of Graphic Design defines graphic design: "In the contemporary world the activity of organizing signs and symbols, or words and images for public exchange is recognized as graphic design-a specialist area of the broader field of design" [1, p.6]. The Compact Oxford English Dictionary (2003) defines graphic design as "the art of combining text and pictures in advertisements, magazines and book".[6]

In the definitions mentioned above, the organization of text and visuals is emerging as a common characteristic and an essential function of graphic design, employing printing for information dissemination. A more recent vantage point gives way to a disparate view throwing light on its expanded functions. AIGA had published an article on its website titled What is Graphic Design? Written by Cezzar[7], the article discussed the role of graphic designers not confined to the making of products but also systems with a thorough understanding and application of the design process. The author stresses, designers of today prioritize usability and functionality over aesthetic expression. Further, team management, client relations are expected skills in present times. In the same article, Cezzar [7] describes graphic design as follows:

Graphic Design, also known as communication design, is the art and practice of planning and projecting ideas and experiences with visual and textual content. The form it takes can be physical or virtual and can include images, words, or graphics. The experience can take place in an instant or over a long period of 
time. The work can happen at any scale from the design of a single postage stamp to a national postal signage system. It can be intended for a small number of people, such as oneoff or limited-edition book or exhibition design, or can be seen by millions, as with the interlinked digital and physical content of an international news organization. It can also be for any purpose, whether commercial, educational, cultural or political. [7]

\section{Name Confusion}

Currently, graphic design is functioning under multiple nomenclatures such as graphic design, visual art, and visual communication. Due to the prevalence of various nomenclatures for this field of design, there seems to be an identity crisis. Concerning the multiple titles and confusion around it, McCoy [8, p. 3] asks a valid question: "Are we graphic designers, graphic artists, commercial artists, visual communicators, communication designers or simply layout men and paste-up artists?" Swanson [9] points out that the future job scenario for graphic designers will look drastically different from today. The changing names of programs-from commercial arts to advertising design to graphic design to visual communication and sometimes back to graphic design confirm that though there will be graphic designers in the future, they will be performing tasks that will be different from the tasks performed by graphic designers of today.

Some graphic design programmes have deliberately abandoned the word design and swapped it with the word communication in the title to align itself with some emerging fields of study, such as communication studies. Some institutions have also adopted a more general title, such as visual communication [Julier, 2008 cited by Harland, 12]. Richard Grefe's [11] article titled The Evolving Role of AIGA, The Professional Association of Design, emphasizes the evolving role of graphic design practice from the making of two-dimensional artefacts to creating strategic and conceptual, multi-dimensional experiences. He further states-the inside community of designers is concerned with the specificity of a new name of the evolving profession; however, now the clients seek complex problem solvers and are less concerned about the nomenclature. Hence, the association's name was changed from American Institute of Graphic Arts to AIGA-The Professional Association for Design. He elucidated that members of the organization by training may be graphic designers but also call themselves by other names. Furthermore, He clearly stated that "there was no clear and dominant new name for the profession as it is being practiced". [11]

Peter Kneebone and Willy de Majo founded ico-D on 27 April 1963 in London, as icograda-The International Council of Graphic Design Associations to address the requirement of relevant and purposeful dialogue around the future course of graphic design. In 2011, icograda was re-titled as The International Council of Communication Design to reflect and embrace the emerging graphic design fields and media practices [12].

The book titled The AIGA Guide to Careers in Graphic and Communication Design published in 2018 by AIGA and authored by Cezzar [13] shows the confusion around the profession's name due to using both graphic and communication design in the title. The World Design Survey 2010, a project to establish an international design knowledge base system, prepared a comprehensive report comprising relevant information on the status of design policy, industry, culture, and education from 17 regions worldwide. This project was an initiative of icograda (now called ico-D). Data sources included original research, published government, research reports, and desk research from 11 countries and six regions. One of the critical areas of this research was collecting and analyzing basic data for defining design and categorizing the design sectors from different regions [14]. The table below presents the collated data from 15 regions based on The World Design Survey 2000 report. Data has been collated from the design sector, elucidating graphic design and its activities. 
Table 1

Names used to describe graphic design related sector by different regions of the world with associated activities in the sector.

\begin{tabular}{|c|c|c|}
\hline Region & Design Sector & Activities \\
\hline Beijing & Communication Design & $\begin{array}{l}\text { Binding design, printing design, packaging, exhibition, visual } \\
\text { design, advertising design }\end{array}$ \\
\hline Hong Kong & Communication Design & $\begin{array}{l}\text { Identity design and branding design, interactive media, packaging } \\
\text { design, publication design, poster design and promotion materials, } \\
\text { typography }\end{array}$ \\
\hline Istanbul & Graphic and Advertising Design & Not specified in the report \\
\hline Montreal & Graphic Design & $\begin{array}{l}\text { Packaging design, video screen displays design, advertising design, } \\
\text { signage systems design, and corporate identification }\end{array}$ \\
\hline Seoul & Visual Communication Design & Not specified in the report \\
\hline Victoria & $\begin{array}{l}\text { Visual Communication/Graphic } \\
\text { Design }\end{array}$ & Not specified in the report \\
\hline India & Graphic Design & $\begin{array}{l}\text { Print design-brochures, books, leaflets, flyers, posters; packaging } \\
\text { design, branding strategy, visual communication product graphics, } \\
\text { POP graphics, website design, e-catalogue design; Miscellaneous } \\
\text { design—-menus, newsletters, signage, etc. }\end{array}$ \\
\hline Indonesia & Visual Communication Design & Not specified in the report \\
\hline Ireland & Visual Communication & Not specified in the report \\
\hline Japan & Graphic Design & Not specified in the report \\
\hline Korea & Visual Communication & $\begin{array}{l}\text { Illustration, typography, photography, advertisement design, } \\
\text { editing/publishing design, identity design, package design, } \\
\text { promotion, environmental graphics }\end{array}$ \\
\hline Netherlands & Graphic Design & Not specified in the report \\
\hline South Africa & Communication Design & Not specified in the report \\
\hline Taiwan & Visual Communication Design & $\begin{array}{l}\text { Corporate identity design, brand, graphic design, advertising } \\
\text { design, website design, and multimedia }\end{array}$ \\
\hline $\begin{array}{l}\text { United } \\
\text { Kingdom }\end{array}$ & Graphic Design & $\begin{array}{l}\text { Type design, typography, lettering and calligraphy for } \\
\text { reproduction; Illustration, advertising design; Design for print- } \\
\text { annual reports, brochures, books and magazines; Design for two } \\
\text { and three-dimensional packaging; Corporate identity, Applied } \\
\text { graphics including signing systems; Vehicle livery and graphics on } \\
\text { product design, Architectural graphics; Design for film, television } \\
\text { or video reproduction-multi-sensual, time-based or still imagery; } \\
\text { Photography }\end{array}$ \\
\hline
\end{tabular}

Note: The data has been collected from the summary of the World Design Survey 2010. Research Report Source: (https:// www.icod.org/database/files/library/WDS2010_WorldDesignSurvey.pdf) Retrieved: February 11, 2020

Analysis of the data in Table 1 reflects that different umbrella terms (for the design sector) such as graphic design, communication design, graphic and advertising design, visual communication

design, and visual communication/graphic design are used to categorize the activities in different regions. This points towards inconsistencies in nomenclature worldwide for the design sector under consideration as varied titles are used for a similar spectrum of activities. Further, The World Design Survey 2010 [14] project research report brings forth some variance in the design sectors categorization within different regions. In some places, web design, packaging design, multimedia and web design, new media 
design, exhibition design, interaction design emerge as independent design sectors. While in other regions, these come under the collective banner of graphic design, communication design, graphic and advertising design, visual communication design, or visual communication/graphic design.

\section{What Should It Be Called?}

Some scholars and practitioners opine that the process of organization continues to be an important part of graphic design. However, graphic design has moved beyond its traditional praxis in the present times. Bernard points out that to change the existing perception of the public about graphic design as skilled "wrist-for-hire" trade or vocation to a respectable and high paid "visual-intellect" profession-the name change may be necessary [Bernard, 1999, pp. 23-25 cited by Damon 3, p. 29]. The change will help justify its wider and valuable contribution to society, which is not limited to just the visual rhetoric of looking pretty. A logical justification has been given by the design sector report called Shaping Canada's Future by Design, sponsored by HRDC. The report mentions that graphic design has strong ties with printing because, at one time, it was the only source of dispensing information and communication to the public and business environment [15]. Further, Damon [3] points out that a graphic designer's conventional role entailed the organization of text and images for reproduction through printing technology; however, at present times, designs employing printing continue but facilitated by varied computer software. Furthermore, due to the changing needs of the marketplace and the emergence of new technologies, graphic design has become an umbrella term for a more and more varied assortment of specializations. Thus, the professional designers and graphic design educators strongly feel that the term graphic design is a passé as the profession has moved much further than connecting it only with printing based information and communication.
Several names have been proposed from time to time for graphic design as there are plenty of new functions attached to it in the present times. There are diverse views about the necessity of a new name and a lack of consensus about proposed nomenclatures. In the icograda (International Council of Graphic Design Associations now called ico-D) Design Education Manifesto, Seoul 2000 with reference to the change of name, Poggenpohl \& Ahn [16] in support of the term "visual communication design" stateit is an umbrella term that integrates within itself the expression and reflection of several other disciplines. According to them, the term graphic design is technically week, and a better term is visual communication design.

Jorge Frascara [18, p.1], in his book Communication Design-Principles, Methods, and Practice, indicates: "Design is generally understood as the physical product derived from the activity, but the activity itself is often overlooked" $[18$, p.1]. While expressing his views in favour of the visual communication design, he says:

"Although the most widely accepted term is indeed 'graphic designer', it is more descriptive and appropriate to say 'visual communication designer', because this definition includes three essential elements of the profession: a method (design); an objective (communication); and a medium (vision)" [18, p. 4].

There are some emerging trends such as graphic design being listed under the broader category of visual communication or replacement of graphic with the word communication. Gerfe, in his article on AIGA website, mentions that the mid-century graphic designers concentrated on form, but their role expanded by the 1980s, and the designers became responsible for form as well as the content of messages they designed. Hence, came to be known as communication designers [18]. 


\section{Indian Context}

Understanding has been sought from the education sector to comprehend the discrepancies in programme names and some emerging terms. Data has been collected from the official websites of different educational institutes and government reports to throw some light on the emerging trends and expanded scope of graphic design.

Confederation of Indian Industries (CII) in The India Design Report [19] published in the year 2011 defines graphic design:

Graphic design is the process of visual communication which combines words, images and ideas to present the information to the audience. A graphic designer is a specialist in solving the problems associated with visual communication. The potential of graphic design covers areas ranging from social communication to corporate communication and branding. Some of the multi-dimensional aspects of graphic design cover typography and type design, photography, illustration, graphic interface design, packaging, print design, corporate identity, branding and information and communication systems like signage. [p. 44]

\section{The Scope}

Industrial Design Centre (IDC) ${ }^{1}$, Indian Institute of Technology (IIT), Bombay, in its proposal titled Empowering Communication/ Graphic Design Education in India, while elaborating on the scope of graphic design

1 "Industrial Design Centre Industrial Design Centre was set up in 1969 by the Government of India under the auspices of Indian Institute of Technology Bombay". [20] It is popularly known by the acronym IDC.

The establishment of India Design Council was announced in the year 2009 in pursuance of National Design Policy adopted by the Government of India in 2007. The India Design Council also shares the same acronym but to avoid confusion, for this study, "IDC" as an acronym has been used for Industrial Design Centre. stressed, communication/graphic design has been the backbone of many industries like print and publishing, advertising, media, packaging, exhibition, web, and signage industry with its multiple functionsIdentity, branding, retail strategy, advertising, promotion through the use of typography, photography, illustrations, and animation [21].

With design emerging as a dynamic sector in India today, the India Design Report endorsed by The India Design Council was released by the Confederation of Indian Industries (CII) in 2015. The India Design Report is a comprehensive document examining various aspects of the design industry, design policy, and design education. The report throws light on the scope of work of graphic designers in India. It explains that graphic designers work in design agencies, advertising agencies, corporate communication departments of businesses or independently in the area of Information design, type design, packaging design, environmental graphics, film title design, TV graphics, signage design, publication system design, system design, illustrations, strategic design, etc. [22].

\section{Nomenclatures Used in Education}

In India, there is a presence of undergraduate programmes, post-graduate programmes, diploma and certificate courses in graphic design education. For this study, only undergraduate degree programmes have been examined.

In India, graphic design undergraduate degree programmes fall under different titles, such as the four-year programme in communication design, visual communication, graphic and communication design, graphic design, visual arts, etc. Some programmes lead to Bachelor of Design (B. Des) degree after 12 years of school education. Further, within graphic design, there is a substantial presence of a programme called Applied Arts. It is a four-year program post 12 years of school education [19], leading to Bachelor of Visual Arts (B. V. A) degree [23]. Initiating this programme requires 
approval from the All India Council for Technical Education in addition to university affiliation. The students, after completing this programme are absorbed by the advertising industry for employment [19].

Literature review reveals that graphic design came to India with the art schools. Sir JJ School of Art that started as an Arts and Crafts institution, was established in 1857. In 1935, it established the Department of Commercial Art, which is said to have laid down the foundations for graphic design in India. [24]. Design in India [25] while tracking the beginning of design education in India, informs-the art schools in India were established in the 1800s, Bombay Art School, which is now called Sir J J School of Arts, was established in 1857. M S U School of Arts in Baroda and College of Arts in Kolkata in 1887 and 1884 respectively followed by others. Furthermore, besides fine arts, these art schools offered varied other courses such as pottery, tile making, metal crafts, etc.; however, in the 1950s the art schools started offering graphic design programme namely commercial arts or applied arts to meet the requirements of media and publishing in the country. Prabhakar [25. p. 301z], quotes Charles R. Gerrard-the former director of sir JJ School of Arts in Bombay:

"Looking back over the years, in fact, as far back as 1935 when as a Deputy Director I introduced the subject of commercial art in India, I am glad the subject has been rechristened 'Applied Art' which expresses itself as art applied to everyday life" [25. p. $301 z]$. It is interesting to note the prevalence of these nomenclatures in some educational programmes (commercial arts and applied arts) owing to their historical roots. Further, some nomenclatures are being interchangeably used, and some coexist while serving the same purpose. IDC, IIT, Bombay [20, p. 3] in its proposal-Empowering Communication/ Graphic Design Education in India stated: "Communication or graphic design is also known by other names such as commercial art, applied arts, graphic arts, etc." [20, p. 3]. While illustrating the trajectory of design education in India, Design for India documents that the National Institute of Design (NID) was established in 1960 in Ahmedabad on the basis of the report submitted to the Government of India by well-known designers called Charles and Ray Eames. NID started with the basic design programme and later added Industrial Design and Visual Communication [25]. The establishment of NID laid the foundation of formal design education in the country independent of art schools. In present times, design education in India has also become a part of the universities offering four years of B. Des degree program in different design disciplines. The India Design Council 2011 report states (besides the four-year programmes at the undergraduate level) there are also post-graduate programmes, diploma, and certificate courses in the Indian design education system [19].

The proposal submitted on behalf of communication/graphic design educational institutes in India by IDC, IIT, Bombay [21] titled Empowering Communication/ Graphic Design Education in India has used communication/graphic design together throughout the proposal suggesting that the term communication design and graphic design can be interchangeably used. Therefore, for the purpose of this study and to seek clarity on nomenclatures prevalent in educational programmes, data of twenty design institutes located in various Indian states were collected from their official website. These design programmes mentioned in the table below offer four year B. Des degree in graphic design either directly or under a larger umbrella.

Looking at the data in Table 2, it appears that while the term "graphic design" stands strong, "communication design" seems to be emerging as a popular nomenclature used as an umbrella term under which graphic design, animation film design, exhibition design, film and video design, user experience design have been categorized in some Indian design institutes. Further, several universities and institutes use the nomenclature visual communication under which a similar assortment of programmes are offered; students enrol in 
Graphic design in search of its identity

Table 2

Programme names in different design institute across various Indian states

\begin{tabular}{|c|c|c|c|}
\hline Name of the Institute & City \& State & Programme Name & Additional Information \\
\hline Avantika University & $\begin{array}{l}\text { Ujjain, Madhya } \\
\text { Pradesh }\end{array}$ & Communication Design & $\begin{array}{l}\text { Under the broad heading of } \\
\text { communication design, specialization } \\
\text { tracks are available }\end{array}$ \\
\hline $\begin{array}{l}\text { Banasthali Institute of Design, } \\
\text { Banasthali University }\end{array}$ & Newai, Rajasthan & Communication Design & \\
\hline $\begin{array}{l}\text { Chitkara School of Art and } \\
\text { Design, Chitkara University }\end{array}$ & Patiyala, Punjab & Visual Communication & \\
\hline $\begin{array}{l}\text { Department of Design, Nirma } \\
\text { University }\end{array}$ & $\begin{array}{l}\text { Ahmedabad, } \\
\text { Gujarat }\end{array}$ & Communication Design & $\begin{array}{l}\text { In the third year of study, from semester } \\
\text { V, the students are offered two pathways } \\
\text { and select a minor specialization } \\
\text { through electives. These are: } \\
\text { 1. Graphics and UI-UX Design } \\
\text { 2. Moving Images: Animation and Film } \\
\text { Design }\end{array}$ \\
\hline DJ Academy of Design & \begin{tabular}{|l|} 
Coimbatore, \\
Tamil Nadu \\
\end{tabular} & Communication Design & \\
\hline $\begin{array}{l}\text { DYPDC School of Design, } \\
\text { Ajeenkya D Y Patil University }\end{array}$ & $\begin{array}{l}\text { Pune, } \\
\text { Maharashtra }\end{array}$ & Graphic Design & \\
\hline GLS Institute of Design & $\begin{array}{l}\text { Ahmedabad, } \\
\text { Gujarat }\end{array}$ & Communication Design & $\begin{array}{l}\text { Under the broad heading of } \\
\text { communication design specializations } \\
\text { offered in graphic design }\end{array}$ \\
\hline $\begin{array}{l}\text { Indus Design School, Indus } \\
\text { university }\end{array}$ & $\begin{array}{l}\text { Ahmedabad, } \\
\text { Gujarat }\end{array}$ & Communication Design & \\
\hline $\begin{array}{l}\text { MIT Institute of Design, MIT } \\
\text { University }\end{array}$ & \begin{tabular}{|l|} 
Pune, \\
Maharashtra
\end{tabular} & Graphic Design & \\
\hline $\begin{array}{l}\text { MRID - Maharaja Ranjit Singh } \\
\text { Geekwad Institute of Design }\end{array}$ & $\begin{array}{l}\text { Vadodara, } \\
\text { Gujarat }\end{array}$ & Communication Design & \\
\hline $\begin{array}{l}\text { NID - National Institute of } \\
\text { design }\end{array}$ & $\begin{array}{l}\text { Ahmedabad, } \\
\text { Gujarat }\end{array}$ & Graphic Design & $\begin{array}{l}\text { Under faculty of communication design } \\
\text { specializations offered in animation film } \\
\text { design, exhibition design film and video } \\
\text { design, graphic design }\end{array}$ \\
\hline $\begin{array}{l}\text { School of Design and Visual } \\
\text { Arts - Apeejay Satya University }\end{array}$ & $\begin{array}{l}\text { Gurugram, } \\
\text { Haryana }\end{array}$ & Graphic Design & $\begin{array}{l}\text { School of design and visual arts offers } \\
\text { four-year programme in fashion } \\
\text { design, graphic design, interior design, } \\
\text { animation and multimedia design }\end{array}$ \\
\hline $\begin{array}{l}\text { School of Design, UPES - } \\
\text { University of Petroleum and } \\
\text { Energy Studies }\end{array}$ & $\begin{array}{l}\text { Dehradun, } \\
\text { Uttarakhand }\end{array}$ & $\begin{array}{l}\text { Graphics and } \\
\text { Communication Design }\end{array}$ & \\
\hline $\begin{array}{l}\text { Shrishti Institute of Art and } \\
\text { Design and Technology }\end{array}$ & $\begin{array}{l}\text { Bangalore, } \\
\text { Karnataka } \\
\end{array}$ & $\begin{array}{l}\text { Visual Communication } \\
\text { and Strategic Branding }\end{array}$ & \\
\hline $\begin{array}{l}\text { Sushant School of Design, } \\
\text { Ansal University }\end{array}$ & $\begin{array}{l}\text { Gurugram, } \\
\text { Haryana }\end{array}$ & Visual Communication & \\
\hline $\begin{array}{l}\text { Symbiosis Institute of Design, } \\
\text { Symbiosis International } \\
\text { (Deemed University) }\end{array}$ & $\begin{array}{l}\text { Pune, } \\
\text { Maharashtra }\end{array}$ & Graphic Design & $\begin{array}{l}\text { Under the broad heading of } \\
\text { communication design, specializations } \\
\text { offered in graphic design, video film } \\
\text { design, animation film design, user } \\
\text { experience design }\end{array}$ \\
\hline The Design Village & $\begin{array}{l}\text { Noida, Uttar } \\
\text { Pradesh }\end{array}$ & Graphic Design & \\
\hline $\begin{array}{l}\text { UID - United world institute of } \\
\text { Design, Karnavati University }\end{array}$ & $\begin{array}{l}\text { Ahmedabad, } \\
\text { Gujarat }\end{array}$ & $\begin{array}{l}\text { Visual Communication } \\
\text { (Graphics) }\end{array}$ & $\begin{array}{l}\text { School of communication design } \\
\text { programmes in visual communication } \\
\text { and animation and motion graphics }\end{array}$ \\
\hline $\begin{array}{l}\text { World University of Design, } \\
\text { School of Communication } \\
\text { Design }\end{array}$ & $\begin{array}{l}\text { Noida, Uttar } \\
\text { Pradesh }\end{array}$ & $\begin{array}{l}\text { Graphic and } \\
\text { Communication Design }\end{array}$ & $\begin{array}{l}\text { School of communication design } \\
\text { offers specialization in graphic and } \\
\text { communication design, animation and } \\
\text { game design, Film and video }\end{array}$ \\
\hline $\begin{array}{l}\text { Woxson School of Art and } \\
\text { Design }\end{array}$ & $\begin{array}{l}\text { Hyderabad, } \\
\text { Telangana }\end{array}$ & Visual Communication & \\
\hline
\end{tabular}

Note: The table has been organized in alphabetical order. The data has been collected from the official websites of each institute/university (Accessed on 26.2.2021). The order in which the contents of the table have been organized does not suggest any hierarchy with regards to the quality of programmes offered by the respective institutes. 
the broad category. However, as they progress to higher semesters, they specialize in a specific area through the elective route. Some programmes allow specializations after a common foundation course in the first year of study. The aim of these undergraduate degree programmes is to prepare students for design praxis.

To understand the situation of discrepancies in nomenclatures, a detailed study of the curricula of these programmes would be helpful in giving a clearer picture of how these programmes are distinct in their offerings. Further, to understand what an applied arts programme entails and to avoid unnecessary confusion for various stakeholders, a careful examination of the curricula of $B$. V. A (Specialization applied arts) degree programme and B. Des. degree programme in Graphic Design offered by different universities in India is required. Owing to overlaps and common characteristics in these programmes of study, it may be helpful to probe deeper to trace its journey in past, where it stands today and what the future holds.

India has formulated and adopted a National Design Policy in 2007 and constituted India Design Council in March 2009 to implement the major provisions of the National Design Policy [19]. The India Design Council has accreditation of design qualifications as one of its mandates. The council, to serve its prime objectives, has constituted three task forces. "The second task force focuses on criteria for benchmarking design educational institutions, training institutes and developing model curriculum" [27]. In India, the governing body for architecture education is The Council of Architecture-a statutory body that licenses architects for practice and also recognizes qualifications [19]. Design does not have any accreditation body to accredit the design programmes; hence, there is a lack of a consistent structure [24]. Further, degrees in India can be awarded only by a university. The university system across the country is governed by the University Grants Commission (UGC). UGC is a statutory organization of the Government of India which has coordination, determination and maintenance of a standard of teaching, examination and research in university education [28]. UGC [23] prepared a model curriculum for Visual arts in 2001 with a goal to provide updated education to students and to take care of the lacuna, defects and shortcomings in the existing curricula in certain universities. The B. V. A degree is awarded post four years of specialization in painting, sculpture, printmaking, or applied arts. The committee of experts found several discrepancies in the nomenclature of the subjects in different universities and institutions and suggested suitable nomenclature for uniformity and also to avoid confusion in admissions or appointments from universities and institutions to other similar organizations [23].

The establishment of the India Design Council was announced in the year 2009 in pursuance of the National Design Policy adopted by the Government of India in 2007. In the area of design education, the council has a specific mandate of benchmarking design institutions; develop standardized design syllabi for all institutions imparting design education in India, and develop model curriculum [27]. Thus, in the future, the council may collaborate with different governing bodies and make recommendations to tackle various discrepancies in curricula and nomenclature; analyse the similarities and differences in applied arts programmes leading to B. V. A degree and other programmes in the area of graphic design/communication design/ visual communication design/graphic and communication design etc. leading to B. Des degree.

\section{Conclusion}

The perception of graphic design being limited to the visual rhetoric or subjecting its focus to mere aesthetic is changing. A review of the literature revealed a role expansion of graphic design as well as a lack of consensus on what it should be called. The reason for the usage of multiple names for the profession seems to be 
based on the fact that the profession has been continuously expanding and growing. The term graphic design seems to have become inadequate and obsolete due to ever-growing domain expansion and inclusion of multiple and dynamic market needs, changing social, political, cultural norms, and other such factors.

Involvement of professional bodies, organizations, government bodies worldwide to analyse trends in practice and their impact on education through relevant data is the need of the hour. The contribution of communities of practice, educationists, and researchers both locally and globally for assessment, negotiations, and advancement is imperative for any change.

Bonsiepe [4] makes a valid argument in the article "A Step Towards the Reinvention of Graphic Design.” The term graphic design and graphic designer are closely linked with printing technology. Therefore, the term graphic design does not encompass the changes taking place owing to technological innovations, especially pertaining to "computers and computerization." The author further stresses: "We observe a growth in the domain that has been called 'retinal space." 2 The newer concepts such as audiovisual means, multimedia, information management highlight the boundaries of conventional views of graphic design. Thus, the changes and the expansion which is taking place require graphic designers to modify their professional skills and attributes. This situation is pressurizing the community to consider the possibility of a new term; however, one needs to understand that such a change might call for a strongly critical, disputatious writing or speech [4].
While referring to different programme titles at D\&AD Young Blood 2012, Harland [10] states an intensive study of the emerging trends internationally and world-over development of graphic design is required to determine how the specialist and non-specialist programmes vary. Damon [3] argues, it is imperative for the design community to articulates the idiosyncrasies of the field of graphic design, or commercial art, or visual communication, or information design, or communication design or interaction design and communicate effectively to the government, business and public at large, or else efforts to update and refurbish the industry with a new name and identity may be a wasteful exercise. In the context of the term graphic design, Damon [3, p.33] states, "while it is easy to understand the dilemma of being stuck with footwear that no longer seems to fit; leaping into a new pair of shoes may result in nothing more than a different set of blisters." A thorough analysis of the past, present, and emerging trends for the future with contribution from its various stakeholders in the industry, practice, education, and research, maybe the way forward. However, "If The Shoes Fit, Keep Wearing Them.”[3]

2 Here the author refers to the aesthetic arrangement of visual and textual components strongly associated with graphic design. Retinal space thus becomes an expression for visual rhetoric involving the creation of eye-pleasing layouts. 


\section{References}

1. Aynsley J. A century of graphic design: Graphic design pioneers of 20th century. Hauppauge, N.Y: Barron's Educational Series; 2001. 256 p.

2. AIGA, The Professional Association for Design. AIGA history timeline [Internet]. 2014 [cited 2020 Feb 3]. Available from: https://www.aiga.org/historytimeline

3. Damon M. The graphic design profession: From margins to mainstream [Internet] Text]. [Vancouver]: University of British Colombia; 2004 [cited $2020 \mathrm{Feb} 1$ ]. Available from: https://open. library.ubc.ca/cIRcle/collections/ubctheses/831/ items/1.0055602

4. Bonsiepe G. A step towards the reinvention of graphic design. Des Issues [Internet]. 1994 [cited 2019 Jan 16];10(1):47. Available from: https://www. jstor.org/stable/1511655? origin=crossref

5. Harland R. The dimensions of graphic design and its spheres of influence. Des Issues [Internet]. 2011 Jan [cited 2020 Feb 5];27(1):21-34. Available from: http://www.mitpressjournals.org/doi/10.1162/ DESI_a_00054

6. Harland R. Redefining the plural domains of graphic design and orientating the subject towards a model that links practice, education and research. In: Emerging Trends in Design Research: Proceedings of the International, School of Design, The Hong Kong Polytechnic University Association of Societies of Design Research (IASDR07) [Internet]. Hongkong: School of Design, The Hong Kong Polytechnic University; 2007. p. 19. Available from: https://repository.lboro.ac.uk/articles/conference_ contribution/Redefining_the_plural_domains_ of_graphic_design_and_orientating_the_subject_ towards_a_model_that_links_practice_education_ and_research/9332444

7. Cezzar J. What is graphic design? [Internet]. AIGA| The Professional Association for Design. 2017 [cited $2020 \mathrm{Feb} 7]$. Available from: https://aigaaix0m5kinte. azurewebsites.net/guide-whatisgraphicdesign

8. McCoy K. Education in an adolescent profession. In: Heller S, editor. The education of a graphic designer. 2nd ed. New York; Garsington: Allworth Press; 2005. p. 3-12.

9. Swanson G. Graphic design education as a liberal art: Design and knowledge in the university and the "real world." In: Heller S, editor. The education of a graphic designer. 2nd ed. New York; Garsington:

Allworth ; Windsor [distributor; 2005. p. 22-32.

10. Harland R. Towards an integrated pedagogy of graphics in the United Kingdom. Iridescent [Internet]. 2012 Jan [cited 2020 Feb 11];2(1):50-60. Available from: https://www.tandfonline.com/doi/ful 1/10.1080/19235003.2012.11428503

11. Grefe R. The evolving role of AIGA, the professional association for design | ico-D [Internet]. Ico-D, International Council of Design. 2006 [cited 2020 Feb 7]. Available from: https://www.ico-d.org/ connect/features/post/244.php

12. ico-D, International Council of Design. History [Internet]. ico-D, International Council of Design. 2015 [cited 2020 Feb 9]. Available from: https://www. ico-d.org/about/history

13. Cezzar J. The AIGA guide to careers in graphic and communication design. New York: Bloomsbury Academic, An imprint of Bloomsbury Publishing Inc; 2018.224 p.

14. World Design Survey 2010 [Internet]. Seoul; 2011 [cited 2020 Feb 11] p. 121. Available from: https:// www.ico-d.org/database/files/library/WDS2010_ WorldDesignSurvey.pdf

15. Human Resources Development Canada. Shaping Canada's future by design [Internet]. Canada: The Design Sector Steering Committee; 1996 [cited 2021 Feb 21] p. 196. Available from: https://gdc.design/ tools-resources/design-buyers/shaping-canadasfuture-by-design

16. Poggenpohl SH, Ahn S-S. Between word and deed: The icograda design education manifesto, Seoul 2000. Des Issues [Internet]. $2002 \mathrm{Apr}$ [cited 2021 Mar 1];18(2):46-56. Available from: https://www.mitpressjournals.org/doi/ abs/10.1162/074793602317355774

17. Frascara J. Communication design: Principles, methods, and practice. New York: Allworth; 2004.

18. Grefe R. Insight: defining the studio of 2015 [Internet]. AIGA, The Professional Association for Design. 2013 [cited 2020 Mar 15]. Available from: https://aigaaix0m5kinte.azurewebsites.net/insightdefining-the-studio-of-2015

19. Confederation of Indian Industry (CII). India design report [Internet]. India: Confederation of Indian Industries - CII; 2011 p. 120. Available from: https:// www.cii.in/webcms/Upload/a2.pdf 
20. Industrial Design Centre. Background [Internet]. IDC School of Design. 2017 [cited 2021 Mar 4]. Available from: http://www.idc.iitb.ac.in/abouts/ background

21. Industrial Design Centre, Indian Institute of Technology Bombay. Empowering communication/ graphic design education in India [Internet]. Industrial Design Centre, Indian Institute of Technology- Bombay; 2008. Available from: http:// www.idc.iitb.ac.in/resources/reports/proposalgraphic-design.pdf

22. Confederation of Indian Industry (CII). India design report 2015 [Internet]. India: CII; 2015 [cited 2020 Feb 9]. Available from: https://www.thereforedesign. co.in/cii-india-design-report

23. University Grants Commission. UGC model curriculum - Visual arts [Internet]. Shri Prem Verma on behalf of University Grants Commission at Jeevan Offset Press; 2001. Available from: https://www.ugc. ac.in/oldpdf/modelcurriculum/visual.pdf

24. British Council, India Design Council. The future of design education in India [Internet]. Delhi: British
Council, India Design Council; 2016 [cited 2020 Feb 2] p. 34. Available from: https://www.britishcouncil. in/sites/default/files/the_future_of_design_ education_in_india.pdf

25. Design in India. Design Education - History of Design Education in India, Major Landmarks [Internet]. Designinindia. 2017 [cited 2020 Mar 9]. Available from: http://www.designindia.net/ thoughts/history/design-education

26. Prabhakar SA. A study of Buddhist applied arts and visual communication. IJRAR- Int J Res Anal Rev [Internet]. 2019;6(1):8. Available from: http://ijrar. com/upload_issue/ijrar_issue_20543344.pdf.

27. Governmnet of India. National design policy [Internet]. India Design Council; 2011. Available from: http://indiadesigncouncil.org/pdf/National_ Design_Policy.pdf

28. University Grants Commission. Welcome to Ugc, New Delhi, India [Internet]. University Grants Commission - Quality Higher Education for All. [cited 2020 Mar 9]. Available from: https://www.ugc. ac.in/ 